\title{
CATALYTIC DETRItIATION OF WATER TONF-7705
}

M. L. Rogers, P. H. Lamberger, R. E. Ellis and T. K. Mills

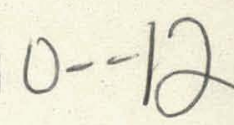

Mound Laboratory*

Miamisburg, Ohio 45342

\begin{abstract}
A pilot-scale system has been used at Mound Laboratory to investigate the catalytic detritiation of water. A hydrophobic, precious metal catalyst is used to promote the exchange of tritium between liquid water and gaseous hydrogen. This catalyst was developed at Chalk River Nuclear Laboratories and is operated at $60^{\circ} \mathrm{C}$.

Two columns are used, each $7.5 \mathrm{~m}$ long by $2.5 \mathrm{~cm}$ i.d. and packed with catalyst. Water flow is $5-10 \mathrm{~cm}^{3} / \mathrm{min}$ and countercurrent hydrogen flow is $9000-12,000 \mathrm{~cm}^{3} / \mathrm{min}$. The equipment, except for the columns, is housed in an inert atmosphere glovebox and is computer controlled. The hydrogen is obtained by electrolysis of a portion of the water stream. Enriched gaseous tritium is withdrawn for further enrichment. A description of the system is included along with an outline of its operation. Recent experimental data are discussed.
\end{abstract}

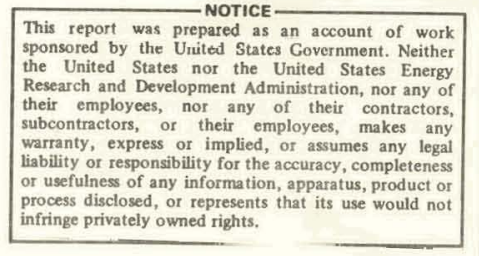

*Mound Laboratory is operated by Monsanto Research Corporation for the U.S. Energy Research and Development Administration under Contract No. EY-76-C-04-0053.

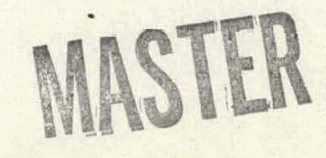




\section{DISCLAIMER}

This report was prepared as an account of work sponsored by an agency of the United States Government. Neither the United States Government nor any agency Thereof, nor any of their employees, makes any warranty, express or implied, or assumes any legal liability or responsibility for the accuracy, completeness, or usefulness of any information, apparatus, product, or process disclosed, or represents that its use would not infringe privately owned rights. Reference herein to any specific commercial product, process, or service by trade name, trademark, manufacturer, or otherwise does not necessarily constitute or imply its endorsement, recommendation, or favoring by the United States Government or any agency thereof. The views and opinions of authors expressed herein do not necessarily state or reflect those of the United States Government or any agency thereof. 


\section{DISCLAIMER}

Portions of this document may be illegible in electronic image products. Images are produced from the best available original document. 
Mound Laboratory has, during the past four years, been actively involved in the development of methods to contain and control tritium during its processing and to recover it from waste streams. Initial bench-scale research was directed mainly toward removal of tritium from gaseous effluent streams. The gaseous effluent investigation has progressed through the development stage and has been implemented in routine operations. A test laboratory embodying many of the results of the research phase has been designed and its construction has been completed.

As the program at Mound Laboratory has progressed, the scope of the effort has been expanded to include research concerned with handling tritiated liquids as well. A program is presently under way to investigate the detritiation of aqueous wastes using the Combined Electrolysis Catalytic Exchange (CECE) process, a process very similar to the CECE-TRP process discussed at this symposium by $\mathrm{Dr}$. Hammerli. As in the CECE-TRP process, the key to our CECE process is a precious metal hydrophobic catalyst developed by Dr. John Butler at Chalk River. Dr. Butler, who discussed this type of catalyst earlier in the symposium, made the catalyst for our system.

\section{Catalytic Exchange}

The catalytic exchange section of the process centers around two catalyst-packed columns, which are arranged in series to operate as if they were the upper and lower sections of a single column. (See Figure 1.) Each column is $7.5 \mathrm{~m}$ in length and has an inside diameter of $2.5 \mathrm{~cm}$, which results in a superficial cross-sectional. area of $5 \mathrm{~cm}^{2}$ and a gross column volume of 3800 $\mathrm{cm}^{3}$. The packing in each column consists of $4300 \mathrm{~g}$ of $0.6-\mathrm{cm}$ diameter catalyst spheres. Liquid redistribution rings are placed at $45-\mathrm{cm}$ intervals throughout the length of each column to limit channeling in the packed sections.

In operation the liquid to be detritiated is supplied at approximately $5 \mathrm{~cm}^{3} / \mathrm{min}$. It is combined with the liquid stream exiting the upper column, and introduced at the top of the lower column. The $10 \mathrm{~cm}^{3} /$ min liquid stream from the bottom of the lower column is routed to the electrolysis section of the process where it is used as feed. Currently, the liquid stream entering at the top of the upper columin is madc up of distilled water, supplied from outside the process. Ultimately, however, this stream is expected to be a'reflux stream, provided by a recombiner or fuel cell which would in turn be fed by the hydrogen product from the upper column.

The hydrogen stream from the electrolysis section is fed to the bottom of the lower column and then is routed to the bottom of the upper column. Upon exiting the upper column, it is currently 
vented to the atmosphere through a stack. As mentioned previously, however, it is anticipated that this stream will later be fed to either a fuel cell or a recombiner to provide reflux to the process and a detritiated liquid product.

Control of the catalytic exchange section of the process consists of five loops, serviced by a single microprocessor. In each of the loops the control element is a metering valve, driven by a stepping motor. For the gas stream passing through the columns, the sensing element is a turbine meter located downstream from the columns. The two liquid feeds to the process are sensed by hot-wire anemometers, and the levels maintained in the bottom of each column are monitored by capacitive level sensors. Although not used in the control of the process, tritium concentrations are monitored at various points by liquid scintillation counters for liquid streams and ion chambers for gas streams.

\section{Electrolysis}

The principal items of equipment in the electrolysis section are four General Electric electrolysis stacks. (See.Figure 2.) Each stack consists of eight cells, each of which has an active area of $46.45 \mathrm{~cm}^{2}$. Current density is $1.076 \mathrm{amp} / \mathrm{cm}$ for the maximum rated current of 50 amps. Rated stack voltage is 16.8 VDC. Cperating at these conditions, each stack electrolyzes $2.45 \mathrm{~cm}^{3}$ water/min to produce approximately $3000 \mathrm{~cm}^{3}$ hydrogen/min and $1500 \mathrm{~cm}^{3}$ oxygen/min. The maximum pressure is $100 \mathrm{psig}$ and the upper limit temperature is $66^{\circ} \mathrm{C}$. Proper stack operation requires that feed water resistivity be maintained at greater than 500,000 $\mathrm{ohm}-\mathrm{cm}$, and that a water circulation rate of approximately 400 $\mathrm{cm}^{3} / \mathrm{min}$ per 8 -cell stack be maintained.

Feed to the electrolysis section is supplied from a feed tank, which also provides recirculation capacity. From the feed tank, the water is pumped through a deionizer, and then to the cells. From the cells, the hydrogen stream passes through a cooler and a phase separator, and is returned to the catalytic exchange section. The oxygen stream, after being routed through a cooler and a phase separator, is currently sent to the air detritiation system for purification and disposal. It is anticipated, however, that this stream will ultimately be fed to a recombiner or a fuel cell supplying reflux to the catalytic exchange columns. The water removed from both the oxygen and hydrogen streams in the phase separators is mixed with the fresh feed upstream from the deionizer, and recirculated through the system.

\section{Preliminary Results}

The CECE system was recently operated continuously for a period of approximately. $48 \mathrm{hr}$. Water was fed both to the top of the first column and in between the columns, each at a rate of 3 
$\mathrm{cm}^{3} / \mathrm{min}$. The top feed had a concentration of $0.028 \mu \mathrm{Ci} /$ liter while the mid-column feed, which can be considered the "hot" feed, had a tritium concentration of $304 \mu \mathrm{Ci} /$ iter. The total electrolysis stream, 7.2 liters/min, was returned to the bottom of the second column.

The depleted hydrogen stream exits the system at the top of the first column, where a portion of this stream is oxidized to water, collected in an ethylene glycol "bubbler", and analyzed for tritium using liquid scintillation counting.. At the end of this 48-hr run, the water formed from this depleted hydrogen had a concentration of $0.006 \mu \mathrm{Ci} /$ liter, while the electrolysis water loop had been enriched to $386 \mu \mathrm{Ci} /$ itier. These results are sumarized in Figure 3.

\section{Future Plans}

The pilot CECE system will continue to be operated with goals of obtaining operating experience, determining scale-up parameters, and improving system dependability. Mound Laboratory also tentatively plans to build a larger system beginning in late 1978 . This system would be used to treat aqueous tritiated waste for ERDA. 


\section{CATALYTIC EXCHANGE SECTION - SIMPLIFIED SCHEMATIC}

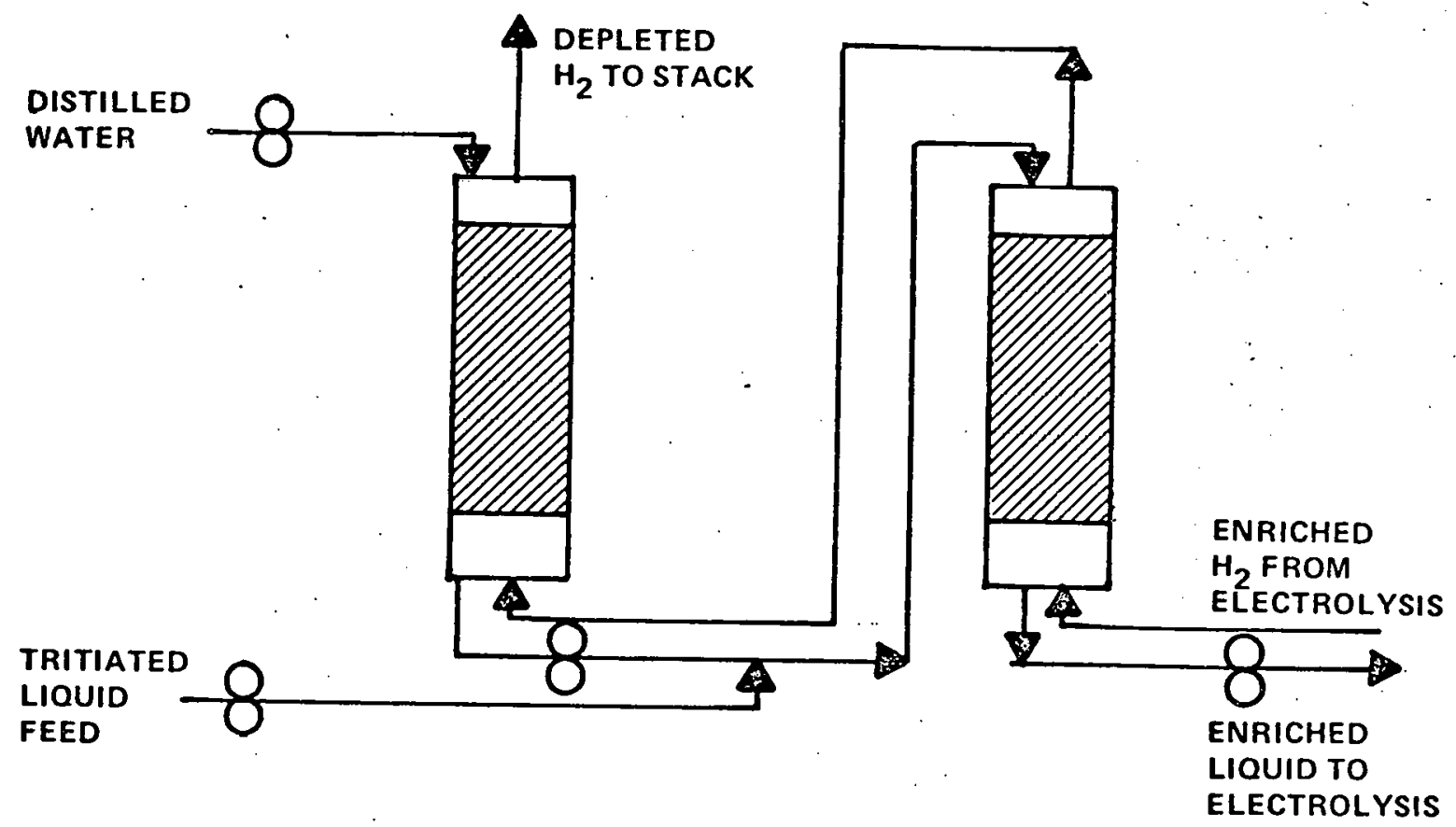

Figure 1 


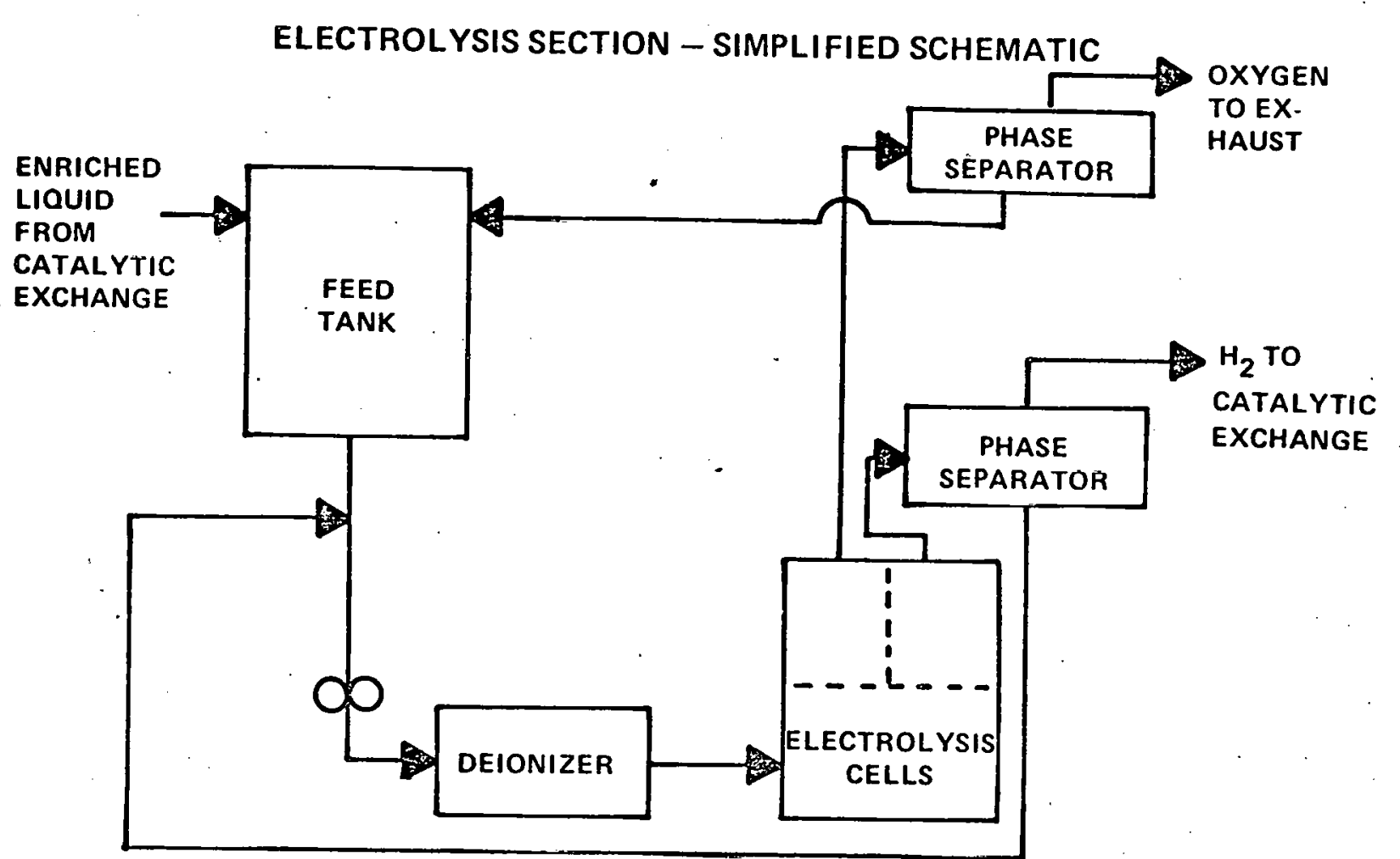

Figure 2 

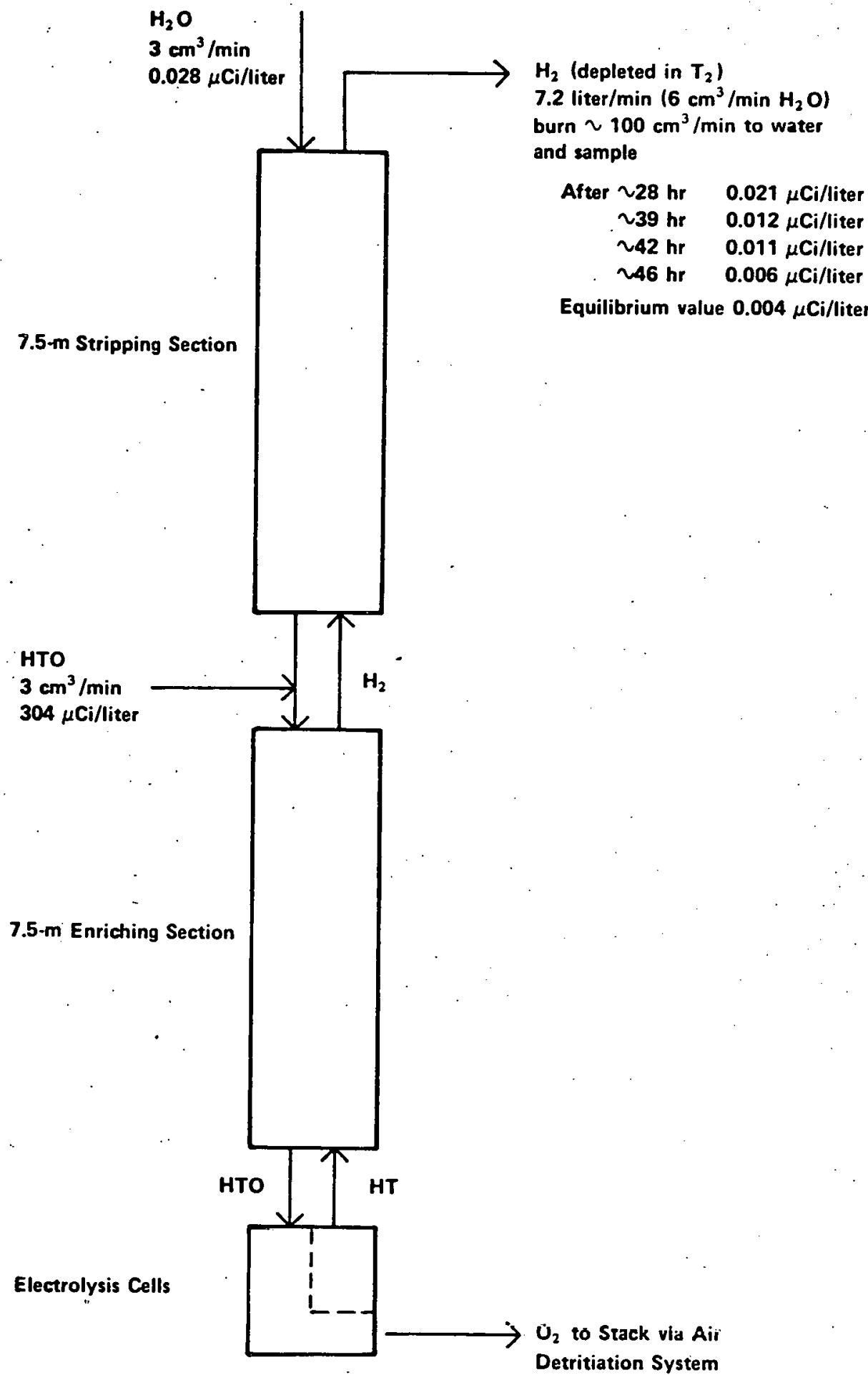

HTO in Cell Loop

$386 \mu \mathrm{Ci} /$ liter After $48 \mathrm{hr}$

Equilibrium Value $\leadsto 2 \mathrm{Ci} / \mathrm{liter}$ 